\title{
Influence of Ca addition on microstructure, mechanical properties and corrosion behavior of Mg-2Zn alloy
}

\author{
*Hong-xiang Li', Shi-kai Qin', Chang-lin Yang', Ying-zhong Ma', Jian Wang1, Yun-jin Liu', and Ji-shan Zhang1 \\ 1. State Key Laboratory for Advanced Metals and Materials, University of Science and Technology Beijing, Beijing 100083, China; \\ 2. State Key Laboratory of Solidification Processing, Northwestern Polytechnical University, Xi'an 710072, China
}

\begin{abstract}
The microstructure, mechanical properties and corrosion behaviors of as-cast ternary $\mathrm{Mg}-2 \mathrm{Zn}-x \mathrm{Ca}$ $(x=0,0.2,0.4,0.8)$ alloys have been investigated in this study. Results indicate that the microstructure of $\mathrm{Mg}-\mathrm{Zn}-\mathrm{Ca}$ alloys can be significantly refined with increasing $\mathrm{Ca}$ concentration. Moreover, the alloys with different contents of $\mathrm{Ca}$ exhibit the different phases formation behaviors, i.e. $\alpha-\mathrm{Mg}+\mathrm{Ca}_{2} \mathrm{Mg}_{6} \mathrm{Zn}_{3}$ phases for $\mathrm{Mg}-2 \mathrm{Zn}-0.2 \mathrm{Ca}$ and $\mathrm{Mg}-2 \mathrm{Zn}$ $0.4 \mathrm{Ca}$ alloys, and $\alpha-\mathrm{Mg}+\mathrm{Ca}_{2} \mathrm{Mg}_{6} \mathrm{Zn}_{3}+\mathrm{Mg}_{2}$ Ca phases for Mg-2Zn-0.8Ca alloy, respectively. Among all the alloys, the maximum ultimate tensile strength and elongation (161 MPa and 9.1\%) can be attained for the Mg-2Zn-0.2Ca alloy. Corrosion tests in Hanks' balanced salt solution indicated that $\mathrm{Ca}$ addition is detrimental to corrosion resistance of $\mathrm{Mg}-2 \mathrm{Zn}$ alloy. The relationship between as-cast microstructure and properties for different Ca-containing alloys is also discussed in detail .
\end{abstract}

Key words: magnesium alloys; Mg-Zn-Ca; microstructure; mechanical properties; corrosion behaviors
CLC numbers: TG146.22
Document code: $\mathrm{A}$
Article ID: 1672-6421(2018 05-363-09

$\mathrm{D}$ ue to low Young's modulus ( $\sim 45 \mathrm{GPa})$, low density $\left(1.7-2.0 \mathrm{~g} \cdot \mathrm{cm}^{-3}\right)$, and good biodegradable properties, magnesium and magnesium alloys are in a region of interest as potential orthopedic, craniofacial, and cardiovascular materials ${ }^{[1]}$. Many researchers are currently developing new biodegradable magnesium alloys and investigating all kinds of properties ${ }^{[2]}$. Among all the alloys, $\mathrm{Mg}-\mathrm{Zn}-\mathrm{Ca}$ especially attracts the scientists' attention because of their high strength (yield strength $>200 \mathrm{MPa}$, ultimate tensile strength $>250 \mathrm{MPa}$ ), high ductility (elongation $>20 \%$ ), moderate bio-corrosion properties, and good biocompatibility ${ }^{[3,4]}$. Summarizing the development status of $\mathrm{Mg}-\mathrm{Zn}-\mathrm{Ca}$ alloys, it is found that $\mathrm{Zn}$ content generally surpasses or equals to $4 \mathrm{wt} . \%$ if $\mathrm{Ca}$ addition is less than $1 \mathrm{wt} . \%^{[1,5-13]}$ or $\mathrm{Zn}$ concentration $<10 \mathrm{wt} . \%$ if $\mathrm{Ca}$ addition is $\geqslant 1 \mathrm{wt}$. $\%^{[14-20]}$. The purpose of high $\mathrm{Zn}$ addition is to ensure high mechanical properties by solid-solution strengthening, grain boundary strengthening and precipitation strengthening, while the role of $\mathrm{Ca}$ is to refine the grain size and enhance the ignition point ${ }^{[21]}$. However, it is also noted that high $\mathrm{Zn}$ or high $\mathrm{Ca}$ concentration is generally detrimental to corrosion resistance ${ }^{[15,22-25]}$. Therefore, the growing trend in

\footnotetext{
*Hong-xiang Li

Male, born in 1974, Ph.D., Associate Professor. Research interests: biodegradable magnesium alloys, mesoscopic simulation for aluminum and magnesium alloys.

E-mail: hxli@skl.ustb.edu.cn

Received: 2017-09-26; Accepted: 2018-03-20
}

recent years is developing low-alloyed $\mathrm{Mg}-\mathrm{Zn}$-Ca alloys, which can coordinate mechanical and corrosion properties simultaneously. For example, Hofstetter et al. developed a $\mathrm{Mg}-1 \mathrm{Zn}-0.3 \mathrm{Ca}$ alloy and obtained a good combination of mechanical and corrosion properties by optimizing hot deformation process ${ }^{[4]}$. Zhang et al. also developed a $\mathrm{Mg}-1.0 \mathrm{Zn}-0.5 \mathrm{Ca}$ alloy by extrusion deformation, which exhibited the strength of $215 \mathrm{MPa}$ and elongation of $44 \%$ ${ }^{[26]}$. From previous studies, it can be found that most of them mainly concentrated on developing the low-alloyed wrought $\mathrm{Mg}-\mathrm{Zn}-\mathrm{Ca}$ alloys. However, learning about the knowledge of the microstructure of as-cast alloys is also very useful in evaluating the properties of wrought alloys, especially understanding phase formation behaviors during age-hardening treatment. To date, few papers to date have been devoted to studying the microstructure of lowalloyed as-cast $\mathrm{Mg}-\mathrm{Zn}$-Ca alloys and understanding the relationship between as-cast microstructure and properties.

Recently, new Mg- $x \mathrm{Zn}-0.2 \mathrm{Ca}$ alloys were developed by the authors and the changes of as-cast microstructure and properties with increasing $\mathrm{Zn}$ content were also investigated ${ }^{[27]}$. However, the effects of $\mathrm{Ca}$ content on the as-cast microstructure, mechanical and corrosion properties in this alloy system were not studied in detail. Based on the above situation, the corresponding work has been performed and the relationship between the as-cast microstructure and properties of different $\mathrm{Ca}$-containing alloys are also discussed in detail. 


\section{Experimental procedures}

\subsection{Materials and preparation of samples}

Alloys of nominal composition $\mathrm{Mg}-2 \mathrm{Zn}-x \mathrm{Ca}(x=0,0.2,0.4,0.8$, by weight percent, hereafter denoted as $0 \mathrm{Ca}, 0.2 \mathrm{Ca}, 0.4 \mathrm{Ca}$ and $0.8 \mathrm{Ca}$ alloys) were prepared from pure $\mathrm{Mg}$ ingot (99.99wt.\%), pure $\mathrm{Zn}$ piece (99.99wt.\%) and $\mathrm{Mg}-33 \mathrm{wt} . \% \mathrm{Ca}$ master alloy. Pure magnesium ingot was first melted in an electric resistance furnace with a low-alloy steel crucible under the protection of $99 \% \mathrm{CO}_{2}+1 \% \mathrm{SF}_{6}$. When the magnesium melt temperature reached $660{ }^{\circ} \mathrm{C}$, pure zinc and $\mathrm{Mg}$-Ca master alloy were added, and then the melt was stirred for 2 minutes. Afterwards, the temperature of the melt was raised to $730{ }^{\circ} \mathrm{C}$ and kept for 15 minutes. After that, the melt was decreased to $700^{\circ} \mathrm{C}$ and poured into the water-cooling copper mold to obtain the as-cast ingots. No homogenization treatment was performed.

\subsection{Microstructure examination and properties tests}

All the specimens for microstructure observation were prepared with standard metallographic procedures. An OLYMPUSBX51M optimal microscopy (OM) and a field-emission scanning electron microscope (FE-SEM) Supra 55 with energydispersive X-ray spectroscopy (EDS) were used to observe the microstructure of different Ca-containing specimens. Average grain size was estimated using the line intercept method on the SEM micrographs. Preliminary examination of phases in ascast alloys was carried out using a Rigaku DMAX-RB X-ray diffractometer with $\mathrm{Cu} \mathrm{K} \alpha$ radiation. The distribution and types of phases were observed by a $200 \mathrm{kV}$ Tecnai G2 F20 transmission electron microscopy (TEM). TEM specimens were prepared by twin-jet electro-polishing (Tenupol-5).

Dog-bone specimens for tensile tests were machined with 35 $\mathrm{mm}$ gauge length, $2 \mathrm{~mm}$ thickness and $10 \mathrm{~mm}$ width. Tensile tests were performed on an Instron5569 materials testing machine at a displacement rate of $1 \mathrm{~mm} \cdot \mathrm{min}^{-1}$. Three parallel specimens were taken for each group experiment in the tensile test.

\subsection{Corrosion tests}

Immersion tests were conducted in a Hanks' balanced salt solution without glucose using the specimens with a dimension of $10 \mathrm{~mm} \times 10 \mathrm{~mm} \times 2 \mathrm{~mm}$. The Hanks' solution was prepared using bi-distilled water and high-purity chemicals according to reference [17]. $\mathrm{pH}$ value of the solution was adjusted to 7.4 at $37 \pm 0.5^{\circ} \mathrm{C}$ through the manual addition of $\mathrm{H}_{3} \mathrm{PO}_{4}$. The immersion solution was refreshed every $24 \mathrm{~h}$. After an immersion for 7 days, samples were removed from the solution and cleaned with chromic acid to remove surface corrosion products without removing any amount of metallic $\mathrm{Mg}$. Then the specimens were rinsed with distilled water, cleaned ultrasonically in acetone, and dried in air. Finally, surface morphologies of corroded samples were observed by SEM.

\section{Results}

\subsection{As-cast microstructure}

Figures 1 and 2 show the as-cast microstructure of Mg-2Zn$x \mathrm{Ca}(x=0,0.2,0.4,0.8)$ alloys observed by OM and EBSD,
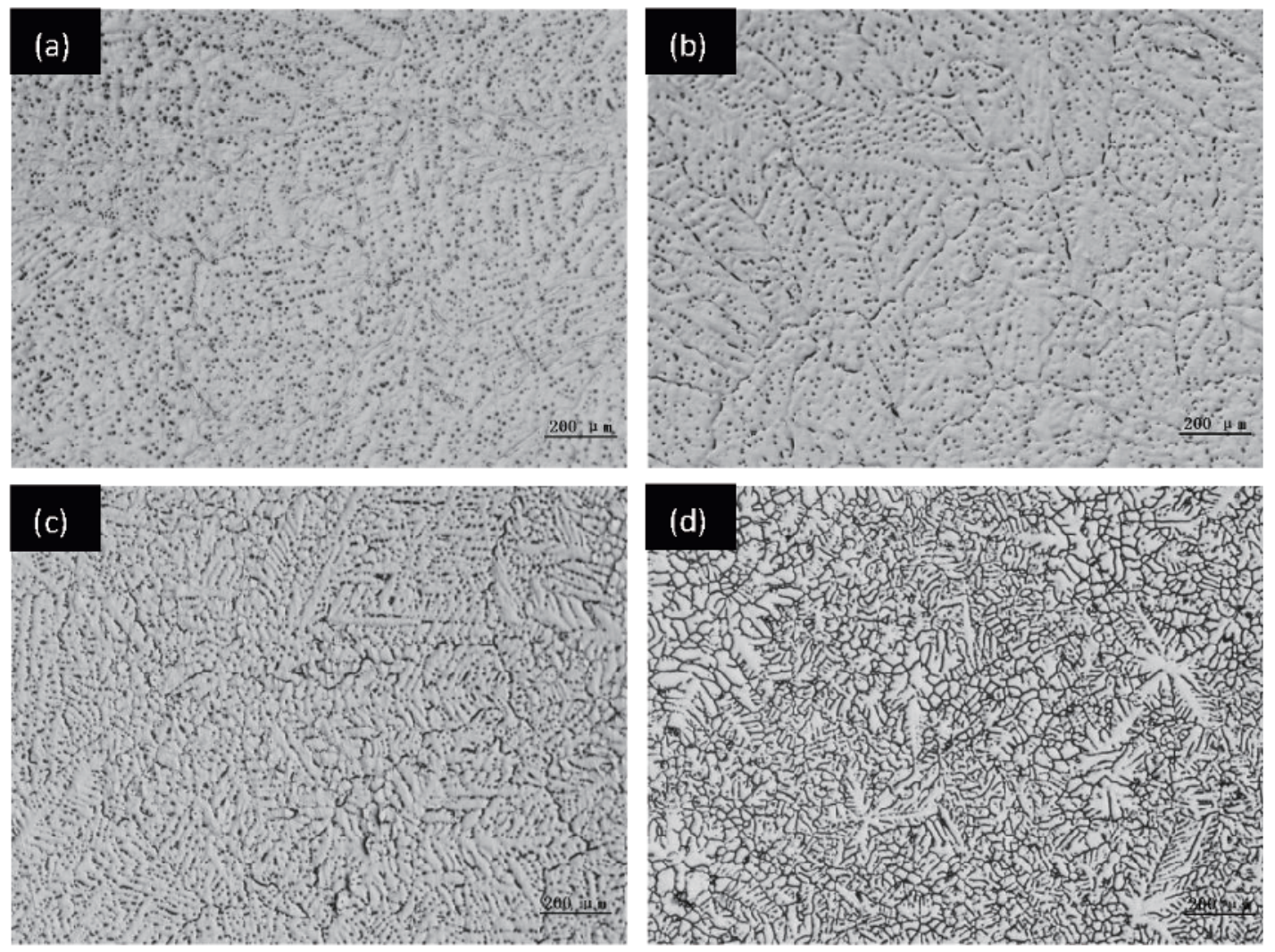

Fig. 1: As-cast microstructure of $\mathrm{Mg}-2 \mathrm{Zn}-\mathrm{xCa}(x=0,0.2,0.4,0.8)$ alloys observed by $\mathrm{OM}$ : (a) $0 \mathrm{Ca}$; (b) $0.2 \mathrm{Ca}$; (c) $0.4 \mathrm{Ca}$; (d) $0.8 \mathrm{Ca}$ 
respectively. From Figs. 1 and 2, it can be seen that with an increase in Ca content, the dendritic structure is becoming very refined, and the addition of $0.8 \mathrm{wt} . \% \mathrm{Ca}$ to $\mathrm{Mg}-2 \mathrm{Zn}$ alloy can induce grain refinement from $388 \mu \mathrm{m}$ to $175 \mu \mathrm{m}$. The positive role of $\mathrm{Ca}$ element in refining the grains has also been reported by other researchers ${ }^{[15-16,21]}$.
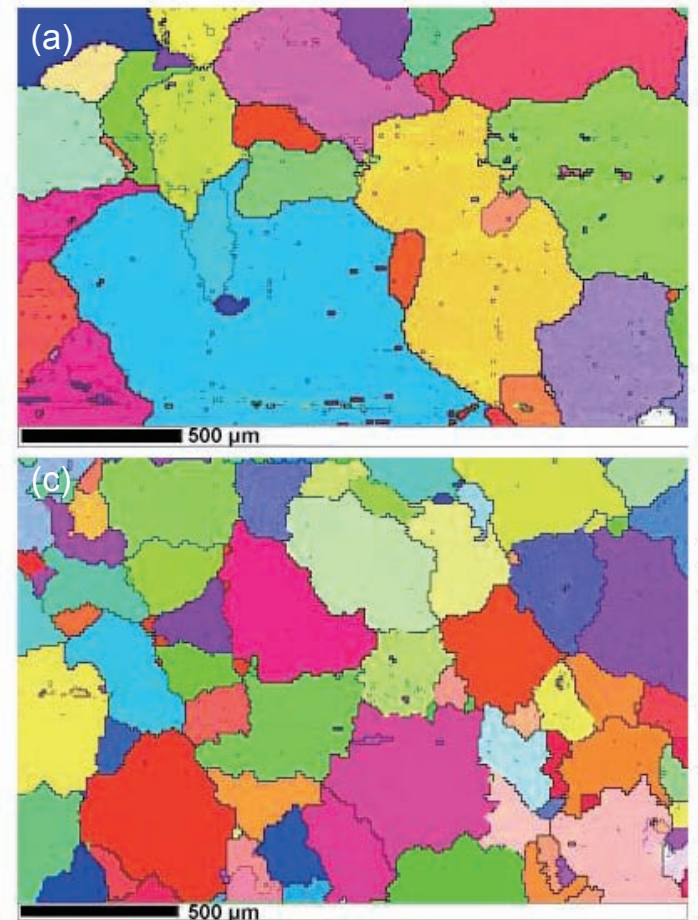

Figure 3 shows the SEM photographs of as-cast Ca-containing alloys. Similar with that as shown in Figs. 1 and 2, it clearly shows the tendency of grain refinement with increasing $\mathrm{Ca}$ concentration. Secondary phase tends to be precipitated along the grain boundary with further $\mathrm{Ca}$ addition. For the $0.8 \mathrm{Ca}$ alloy, the net-like structure can be formed and few granular phases can
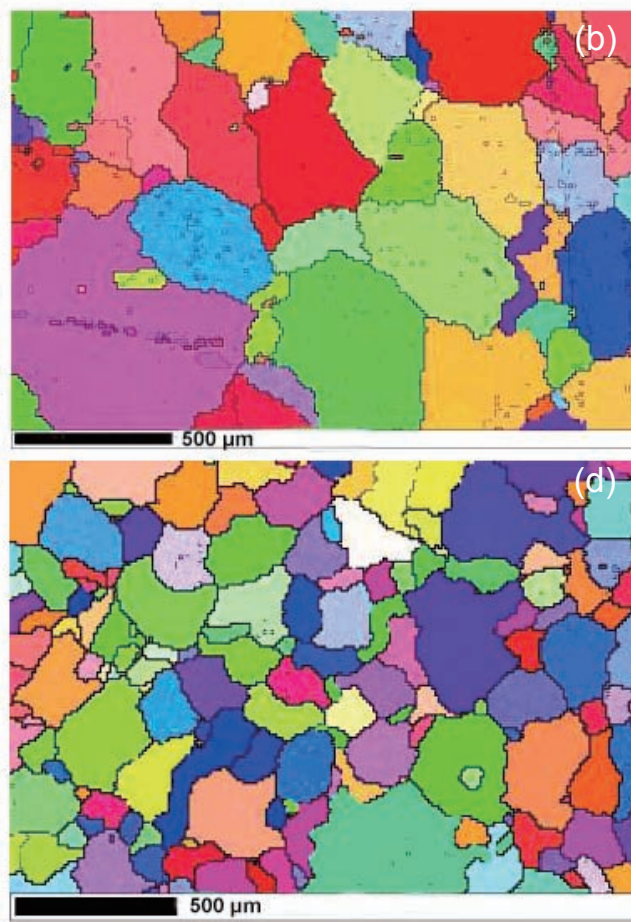

Fig. 2: As-cast microstructure of $\mathrm{Mg}-2 \mathrm{Zn}-\mathrm{xCa}(x=0,0.2,0.4,0.8)$ alloys observed by EBSD: (a) $0 \mathrm{Ca}$; (b) $0.2 \mathrm{Ca}$; (c) $0.4 \mathrm{Ca}$; (d) $0.8 \mathrm{Ca}$
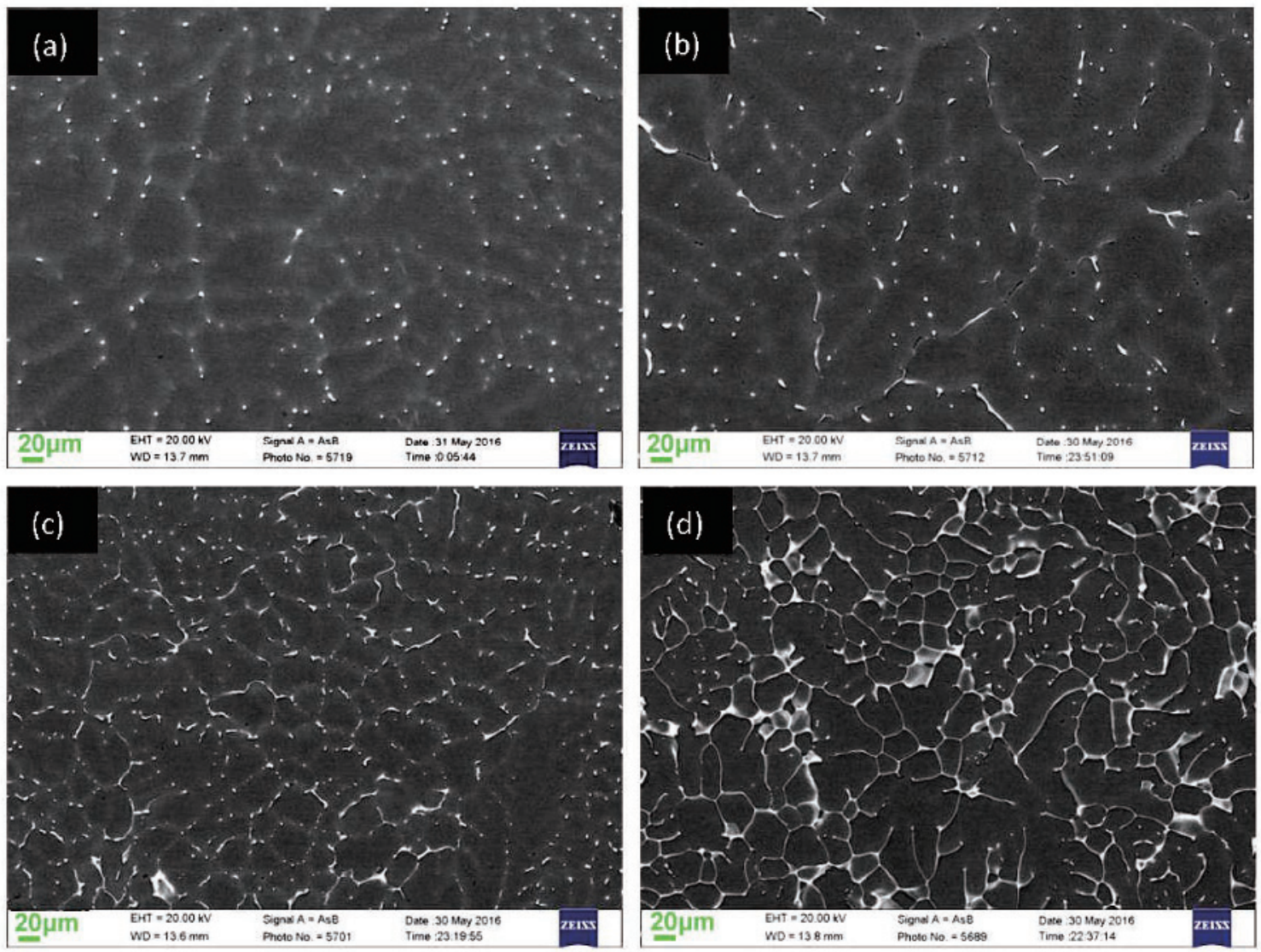

Fig. 3: As-cast microstructure of Mg-2Zn-xCa $(x=0,0.2,0.4,0.8)$ alloys observed by SEM: (a) $0 \mathrm{Ca}$; (b) $0.2 \mathrm{Ca}$; (c) $0.4 \mathrm{Ca}$; (d) $0.8 \mathrm{Ca}$ 
be observed at the inner grains. That is, Ca addition can change the morphology and distribution of the precipitated secondary phase.

To identify the phase constitutes, XRD tests of as-cast samples with different $\mathrm{Ca}$ contents were performed and the patterns are shown in Fig. 4. According to the phase diagrams of binary $\mathrm{Mg}-\mathrm{Ca}, \mathrm{Mg}-\mathrm{Zn}$ and ternary $\mathrm{Mg}-\mathrm{Zn}-\mathrm{Ca}^{[28,29]}$, the maximum solubility of $\mathrm{Ca}$ and $\mathrm{Zn}$ in magnesium is $0.2 \mathrm{wt} . \%$ and $<2.0 \mathrm{wt} . \%$, respectively, at room temperature in the equilibrium state. Thus with the additions of $\mathrm{Ca}$ and $\mathrm{Zn}$ above its solubility limit, excess $\mathrm{Ca}$ and $\mathrm{Zn}$ can appear in the forms of intermetallics as a secondary phase. As seen in Fig. 4, the peaks corresponding to $\alpha-\mathrm{Mg}$ matrix and $\mathrm{MgZn}$ can be observed for $0 \mathrm{Ca}$ alloy, which is confirmed in binary $\mathrm{Mg}$ - $\mathrm{Zn}$ phase diagram. A small amount of granular phase particles precipitated along the grain boundary (Fig. 4a). With increasing Ca content to $0.2 \mathrm{wt} . \%$ and $0.4 \mathrm{wt} . \%$, $\alpha-\mathrm{Mg}$ solid solution $+\mathrm{Ca}_{2} \mathrm{Mg}_{6} \mathrm{Zn}_{3}$ phase can be identified in the XRD pattern. By continuing to increase $\mathrm{Ca}$ content such as $0.8 \mathrm{Ca}$ alloy, it clearly shows that $\alpha-\mathrm{Mg}$ solid solution + $\mathrm{Ca}_{2} \mathrm{Mg}_{6} \mathrm{Zn}_{3}$ phase $+\mathrm{Mg}_{2} \mathrm{Ca}$ phase can be formed. That is to say, different $\mathrm{Ca}$-containing alloys exhibit different phases formation behaviors.

TEM analyses of different Ca-containing alloys were also performed in this study to confirm the characteristics of phases formation. Figure 5 presents TEM bright-field images of ascast $0.2 \mathrm{Ca}$ alloy and the corresponding selected area diffraction patterns (SADP). It can be seen that the alloy matrix is $\alpha-\mathrm{Mg}$ solid solution as indicated by SADP images, taken along [12̄10] zone axis shown in Fig. 5(a, d). From the SADP analysis, $\mathrm{Ca}_{2} \mathrm{Mg}_{6} \mathrm{Zn}_{3}$ phase with strip-like or globular morphologies (zone axis [12 10$]$ and zone axis [0001]), shown in Fig. 5(a, e, and b, f), was observed

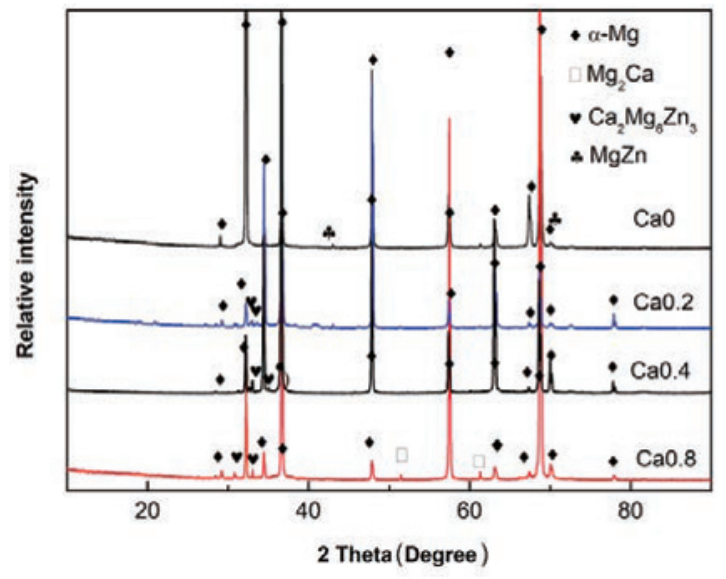

Fig. 4: XRD patterns of as-cast samples for $\mathrm{Mg}-2 \mathrm{Zn}-x \mathrm{Ca}$ $(x=0,0.2,0.4,0.8)$ alloys

in the $0.2 \mathrm{Ca}$ alloy. Meanwhile, it was also found that the ternary $\mathrm{Ca}_{2} \mathrm{Mg}_{6} \mathrm{Zn}_{3}$ phase can coexist with $\alpha-\mathrm{Mg}$ in the forms of eutectic phases, as shown in Fig. 5(c, g).

Figure 6 shows TEM bright-field images and the corresponding SADPs for as-cast $0.8 \mathrm{Ca}$ alloy. From Fig. 6 , it is clear that the precipitated phases basically distribute along the grain boundary and there is the continuous net-like structure, which is in accordance with SEM results shown in Fig. 2. Moreover, few precipitated phases can be observed in the inner grain besides the $\alpha-\mathrm{Mg}$ matrix. The second phase distributing along the grain boundary was identified to be $\mathrm{Ca}_{2} \mathrm{Mg}_{6} \mathrm{Zn}_{3}$ phase (hexagonal structure), as shown in Fig. 6(a, c and d) (a2 and a3, zone axis [24̄23]). Some parallel strip-like phases, marked as a1 in Fig. 6(a), were found to coexist with $\mathrm{Ca}_{2} \mathrm{Mg}_{6} \mathrm{Zn}_{3}$ phase. Further analysis confirmed that
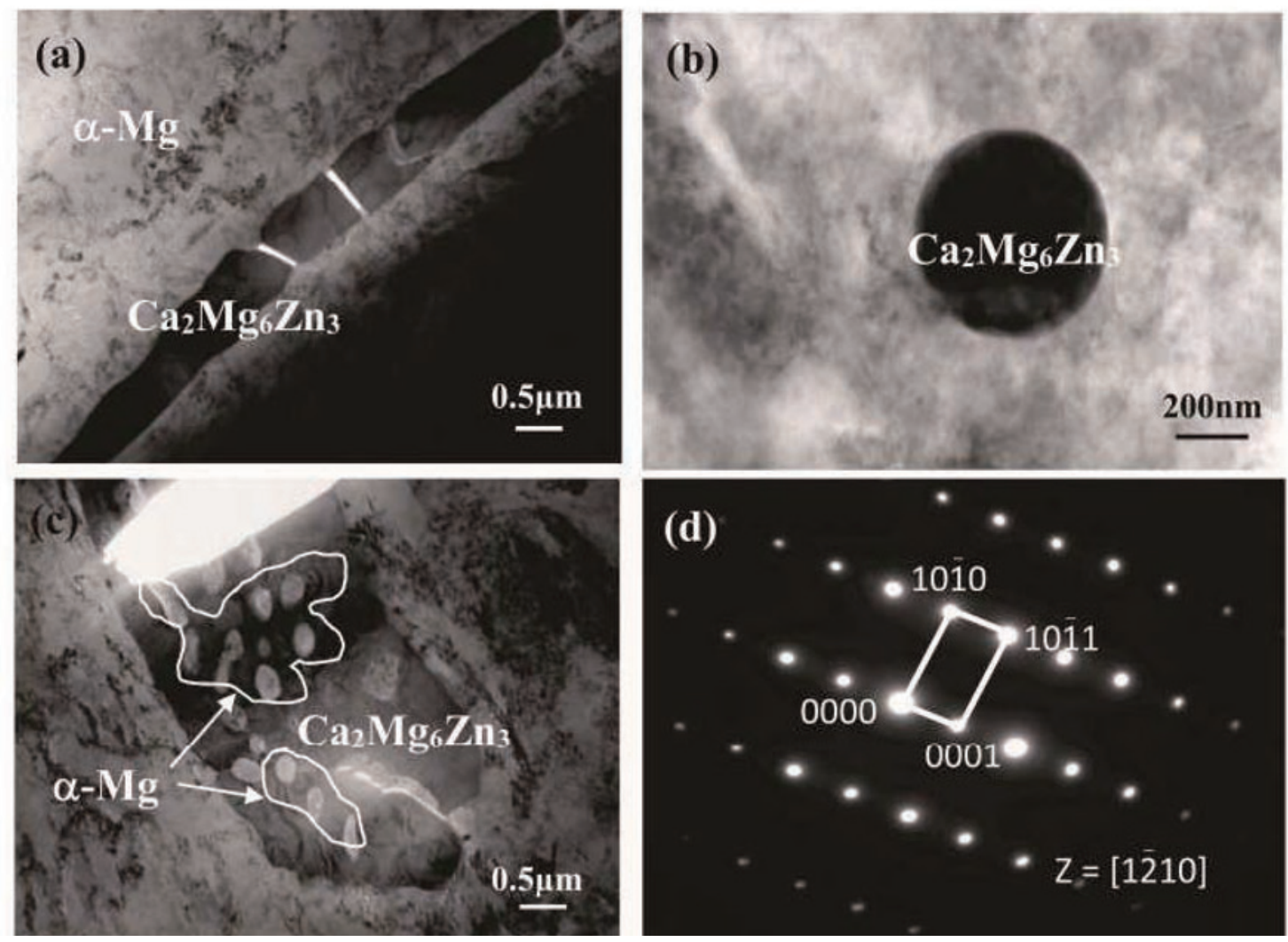

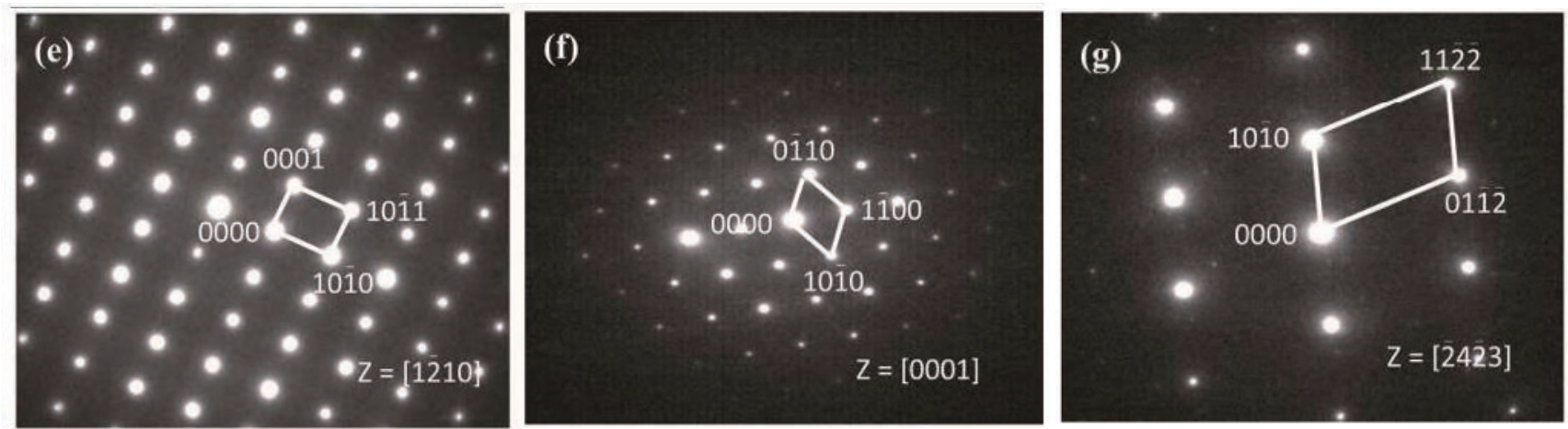

Fig. 5: TEM bright-field images of as-cast $0.2 \mathrm{Ca}$ alloys and corresponding selected area diffraction patterns (SADP): (a) (b)(c) TEM Bright-field images; (d) SADP for $\alpha-M g$ phase shown in (a); (e) SADP for $\mathrm{Ca}_{2} \mathrm{Mg}_{6} \mathrm{Zn}$ 位 phase shown in (a); (f)SADP for $\mathrm{Ca}_{2} \mathrm{Mg}_{6} \mathrm{Zn}_{3}$ phase shown in (b); (g)SADP for $\alpha-M g$ phase shown in irregular line in (c)
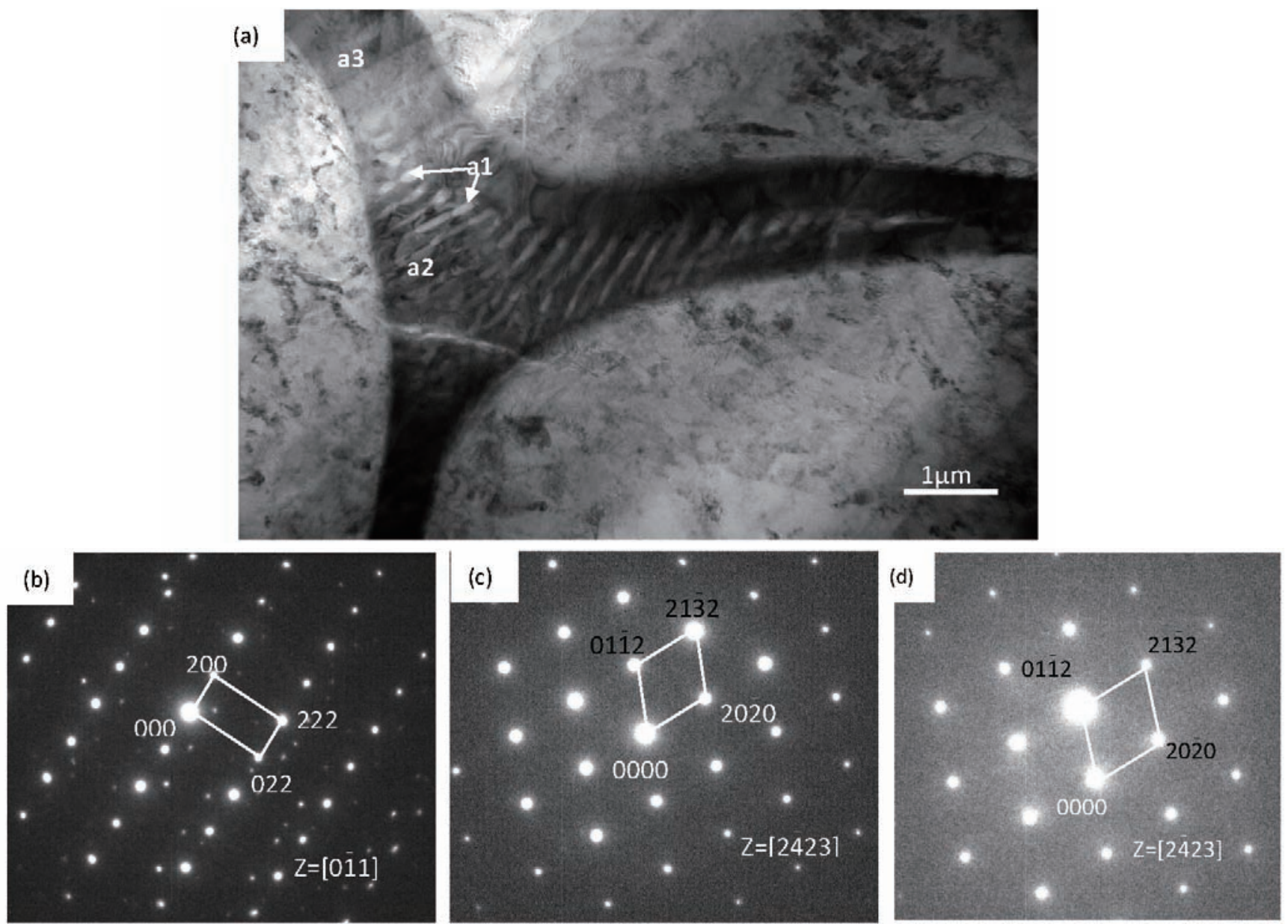

Fig. 6: TEM bright-field images of as-cast $0.8 \mathrm{Ca}$ alloys and corresponding selected area diffraction patterns (SADP): (a) TEM Bright-field images; (b) SADP for a1 phase $\left(\mathrm{Mg}_{2} \mathrm{Ca}\right)$ shown in (a); (c) SADP for a2 phase $\left(\mathrm{Ca}_{2} \mathrm{Mg}_{6} \mathrm{Zn}_{3}\right)$ shown in (a); (d)SADP for a3 phase $\left(\mathrm{Ca}_{2} \mathrm{Mg}_{6} \mathrm{Zn}_{3}\right)$ shown in (a)

these strip-like phases are $\mathrm{Mg}_{2} \mathrm{Ca}$ (monoclinic structure), which can be identified from SADP images, taken along [011] zone axis shown in Fig. 6(b). Compared with Figs. 5 and 6, it clearly shows that with $\mathrm{Ca}$ addition, the microstructure can change from $\alpha-\mathrm{Mg}+$ $\mathrm{Ca}_{2} \mathrm{Mg}_{6} \mathrm{Zn}_{3}$ for $0.2 \mathrm{Ca}$ alloy to $\alpha-\mathrm{Mg}+\mathrm{Ca}_{2} \mathrm{Mg}_{6} \mathrm{Zn}_{3}+\mathrm{Mg}_{2} \mathrm{Ca}$ for $0.8 \mathrm{Ca}$ alloy, which coincides with XRD analysis shown in Fig. 4.

\subsection{Mechanical and corrosion properties}

Tensile strength, yield strength and elongation from different Ca-containing alloys are listed in Table 1. From the table, it is found that tensile strength and elongation firstly increase and then decrease with increasing $\mathrm{Ca}$ content, and $0.2 \mathrm{Ca}$ alloy has the maximum tensile strength and elongation values (161 MPa and 9.1\%) .

Corrosion properties of different Ca-containing alloys after immersion for $168 \mathrm{~h}$ in a Hanks' solution at $37{ }^{\circ} \mathrm{C}$ were also evaluated, and the corresponding results are shown in Fig. 7. It can be seen that with the increase of $\mathrm{Ca}$ content, the corrosion rate continuously increases from $0.14 \mathrm{mg} \cdot \mathrm{cm}^{-2}$ per day for $0 \mathrm{Ca}$ alloy to $0.82 \mathrm{mg} \cdot \mathrm{cm}^{-2}$ per day for $0.8 \mathrm{Ca}$ alloy. For $0.2 \mathrm{Ca}$ and $0.4 \mathrm{Ca}$ alloys, 
Table 1: Alloy composition investigated in this study and their tensile properties

$\begin{array}{lccc}\text { Materials } & \begin{array}{c}\text { Tensile } \\ \text { strength } \\ \text { (MPa) }\end{array} & \begin{array}{c}\text { Yield } \\ \text { strength } \\ \text { (MPa) }\end{array} & \begin{array}{c}\text { Elongation } \\ (\%)\end{array} \\ M M g-2.0 Z n & 123 & 55 & 6.3 \\ M g-2.0 Z n-0.2 \mathrm{Ca} & 161 & 72 & 9.1 \\ \mathrm{Mg}-2.0 \mathrm{Zn}-0.4 \mathrm{Ca} & 143 & 64 & 7.3 \\ \mathrm{Mg}-2.0 \mathrm{Zn}-0.8 \mathrm{Ca} & 132 & 73 & 3.0\end{array}$

the middle value of corrosion rate can be attained, i.e. $0.17 \mathrm{mg} \cdot \mathrm{cm}^{-2}$ per day and $0.28 \mathrm{mg} \cdot \mathrm{cm}^{-2}$ per day, respectively.

Figure 8 shows SEM micrographs of the corroded products after immersion for $168 \mathrm{~h}$ in a Hanks' solution at $37^{\circ} \mathrm{C}$. From Fig. 8, it can be seen that the insoluble corrosion layer with a number of cracks was formed on the surface of different $\mathrm{Ca}$-containing alloy samples. The formation of cracks resulted from the dehydration of the surface layer in air. With the increase of $\mathrm{Ca}$ content, the thickness of the corrosion layer increased, and the width and depth of the cracks produced in the corrosion layer also enlarged. The crack width and depth in the corrosion layer of the $0.8 \mathrm{Ca}$ alloy were the largest ( Fig. 8d).

After removing the corrosion products, SEM surface micrographs were taken and are shown in Fig. 9. It can be seen

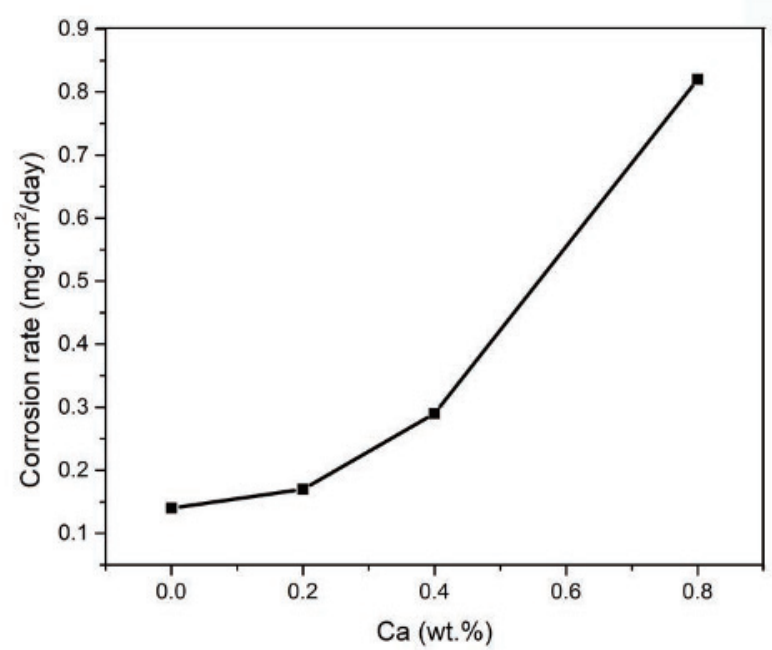

Fig. 7: Corrosion rate of $\mathrm{Mg}-2 \mathrm{Zn}-\mathrm{xCa}(x=0,0.2,0.4,0.8)$ alloys after immersion for $168 \mathrm{~h}$ in a Hanks' solution at $37^{\circ} \mathrm{C}$

from Fig. 9(a), (b), and (c) that different Ca-containing alloys have different corrosion surface morphologies. A large amount of dense pitting corrosion holes can be seen for $0 \mathrm{Ca}$ alloy and the corrosion is relatively uniform. Compared with $0 \mathrm{Ca}$ alloy, the corrosion of $0.2 \mathrm{Ca}$ alloy is more serious and the corrosion holes are obviously dense, and the size of these holes is large. For $0.8 \mathrm{Ca}$ alloy, these pitting corrosion holes are interconnected and the corrosion cavities
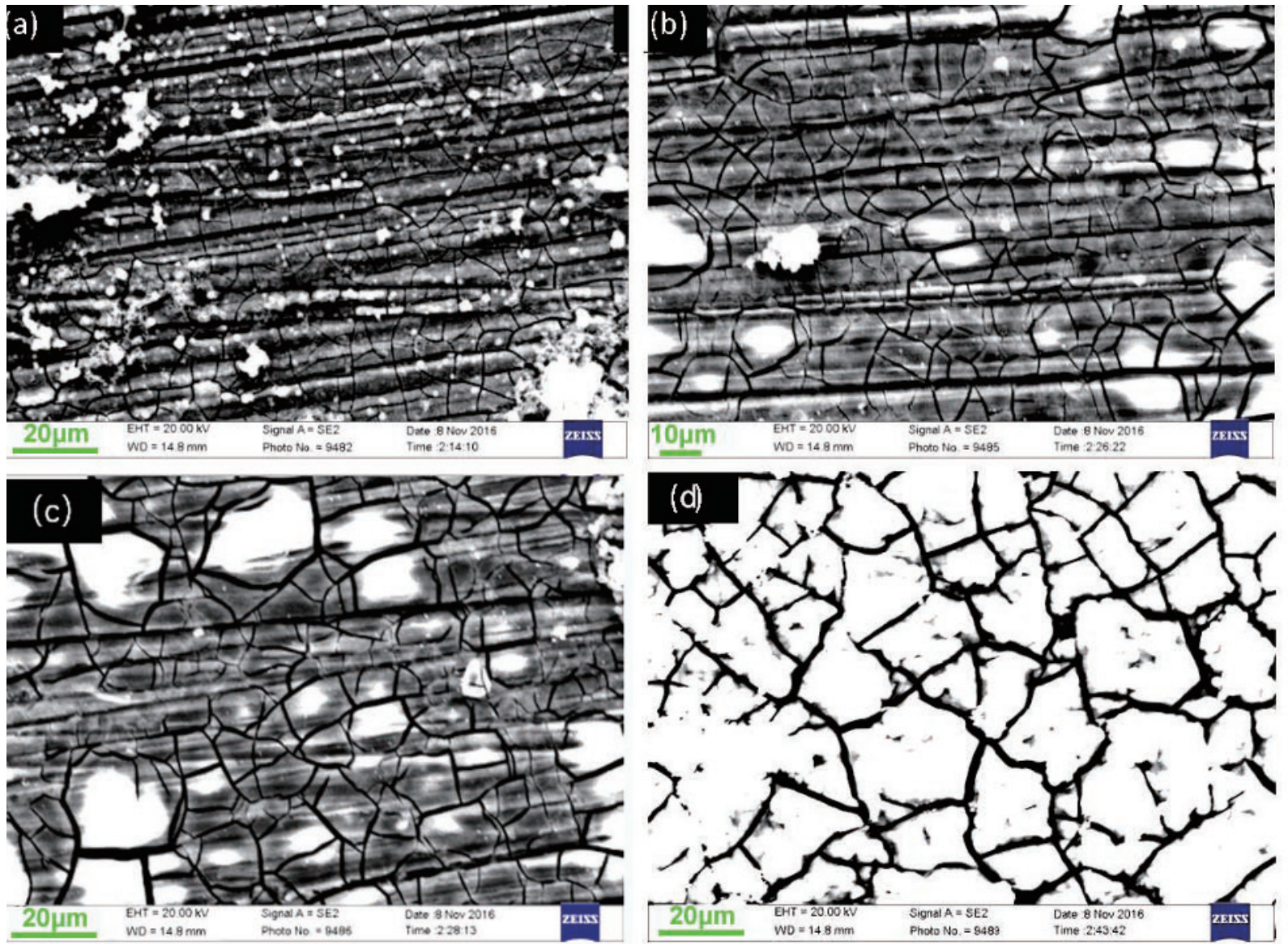

Fig. 8: SEM micrographs of corroded products of $\mathrm{Mg}-2 \mathrm{Zn}-\mathrm{xCa}(x=0,0.2,0.4,0.8)$ alloys after immersion for $168 \mathrm{~h}$ in Hanks' solution at $37^{\circ} \mathrm{C}$ : (a) $0 \mathrm{Ca}$; (b) $0.2 \mathrm{Ca}$; (c) $0.4 \mathrm{Ca}$, (d) $0.8 \mathrm{Ca}$ 

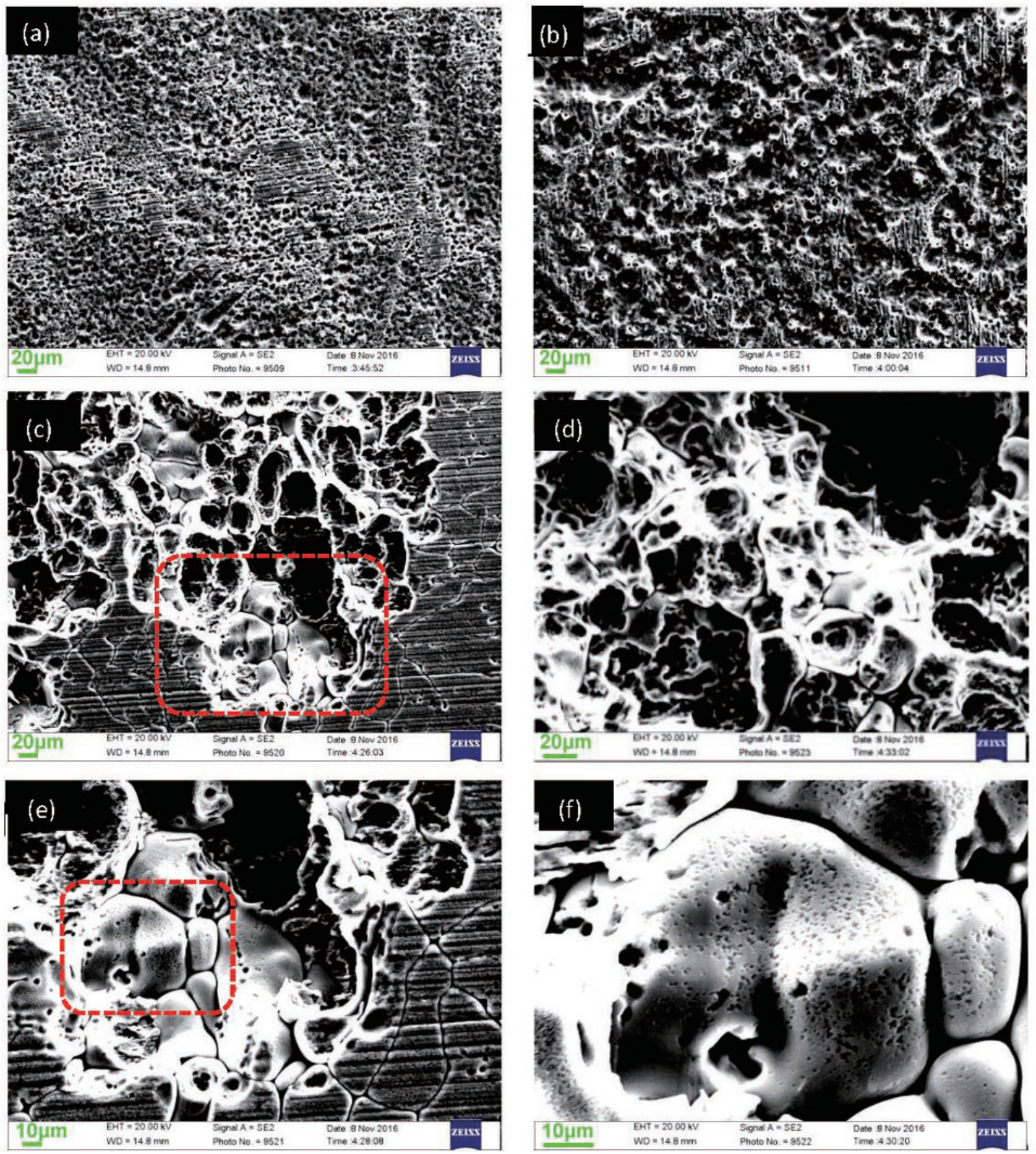

Fig. 9: SEM micrographs of corroded surface of $\mathrm{Mg}-2 \mathrm{Zn}-\mathrm{xCa}(x=0,0.2,0.8)$ alloys after removing the corrosion products: (a) $0 \mathrm{Ca}$; (b) $0.2 \mathrm{Ca}$; (c)and (d) $0.8 \mathrm{Ca}$; (e) magnified micrographs shown in rectangular shape in (c); (f) further magnified micrographs shown in rectangular shape in (e)

with different sizes are produced. These corrosion cavities could propagate from the surface to the inner layer and even go through sole grains to form.

\section{Discussion}

In this study, the grain refinement of $\mathrm{Mg}-2 \mathrm{Zn}$ alloy with more $\mathrm{Ca}$ addition is very obvious. This can be attributed to the formation of constitutional undercooling in a diffusion layer ahead of the solid/liquid interface. Due to the accumulation of alloying elements ( $\mathrm{Ca}$ and $\mathrm{Zn}$ ) at the front of grain growth which limits the growth stage, the grain size is decreased ${ }^{[30]}$.
From the microstructure analysis shown in Figs. 3-6, it can be found that when $\mathrm{Ca}$ content is $0.2 \mathrm{wt} . \%$ and $0.4 \mathrm{wt} . \%$, only two phases are formed: $\alpha-\mathrm{Mg}+\mathrm{Ca}_{2} \mathrm{Mg}_{6} \mathrm{Zn}_{3}$. With more $\mathrm{Ca}$ addition, three phases, i.e. $\alpha-\mathrm{Mg}+\mathrm{Mg}_{2} \mathrm{Ca}+\mathrm{Ca}_{2} \mathrm{Mg}_{6} \mathrm{Zn}_{3}$, can be formed in the as-cast samples. Moreover, the binary phase $\mathrm{Mg}_{2} \mathrm{Ca}$ can be embraced by the ternary phase $\mathrm{Ca}_{2} \mathrm{Mg}_{6} \mathrm{Zn}_{3}$, and thus may serve as a nucleus for the ternary phase ${ }^{[16]}$, as shown in Fig. 6(a). From the OM and SEM images shown in Figs. 1 and 3, it is clear that the volume fractions of the secondary phases increase with the increase of $\mathrm{Ca}$ content, leading to more interlinked phases on the grain boundaries. Thus for $0.8 \mathrm{Ca}$ alloys as seen in Fig. 2, the precipitated phases can be assembled along the 
grain boundary so that the net-like structure can be formed. It is known that the mixing enthalpy between $\mathrm{Zn}$ and $\mathrm{Ca}$ is -22 $\mathrm{kJ} \cdot \mathrm{mol}^{-1}$, which is much greater than that of $\mathrm{Mg}-\mathrm{Zn}\left(-4 \mathrm{~kJ} \cdot \mathrm{mol}^{-1}\right)$ and $\mathrm{Mg}-\mathrm{Ca}\left(-6 \mathrm{~kJ} \cdot \mathrm{mol}^{-1}\right)^{[31]}$. When $\mathrm{Ca}$ is added, it tends to bond with $\mathrm{Zn}$ atoms rather than $\mathrm{Mg}$ atoms and, as a result, $\mathrm{Ca}_{2} \mathrm{Mg}_{6} \mathrm{Zn}_{3}$ phase can be formed. However, with more $\mathrm{Ca}$ addition and the depletion of $\mathrm{Zn}$ atoms for the formation of ternary phases, $\mathrm{Ca}$ can possibly bond with $\mathrm{Mg}$ atoms, leading to the formation of $\mathrm{Mg}_{2} \mathrm{Ca}$ phase. Moreover, with increasing Ca content, the amount of $\mathrm{Mg}_{2} \mathrm{Ca}$ phase formation increases while $\mathrm{Ca}_{2} \mathrm{Mg}_{6} \mathrm{Zn}_{3}$ phase tends to be stable (Fig. 2).

In Table 1, the UTS and elongation of $\mathrm{Mg}-\mathrm{Zn}-\mathrm{Ca}$ alloy increase firstly with the increase of $\mathrm{Ca}$ content and then decrease after the further addition of $\mathrm{Ca}$ element. The increase of UTS for Mg-Zn-Ca alloy with Ca content up to 0.2wt.\% can be firstly speculated from the grain refinement (Figs. 1 and 2 ) according to Hall-Petch law ${ }^{[32]}$. On the other hand, it was reported that ternary $\mathrm{Ca}_{2} \mathrm{Mg}_{6} \mathrm{Zn}_{3}$ phase is an effective strengthening phase, while the binary $\mathrm{Mg}_{2} \mathrm{Ca}$ phase, a brittle phase dispersed along grain boundaries, easily produces crack sources, which can propagate and induce the brittle fracture ${ }^{[6,}$ ${ }^{15},{ }^{33}$. For the $0.2 \mathrm{Ca}$ alloy, only $\alpha-\mathrm{Mg}+\mathrm{Ca}_{2} \mathrm{Mg}_{6} \mathrm{Zn}_{3}$ phases can be formed. With the strengthening role of $\mathrm{Ca}_{2} \mathrm{Mg}_{6} \mathrm{Zn}_{3}$ phase and the grain refinement, it is easy to understand why this alloy can obtain the highest mechanical properties. But for the $0.8 \mathrm{Ca}$ alloy, $\alpha-\mathrm{Mg}+\mathrm{Mg}_{2} \mathrm{Ca}+\mathrm{Ca}_{2} \mathrm{Mg}_{6} \mathrm{Zn}_{3}$ phases can be formed. With the coexistence of $\mathrm{Mg}_{2} \mathrm{Ca}$ and $\mathrm{Ca}_{2} \mathrm{Mg}_{6} \mathrm{Zn}_{3}$ phases, especially the increase of brittle $\mathrm{Mg}_{2} \mathrm{Ca}$ phase, the strength tends to be decreased. In addition, the net-like grain boundary structure weakens the bonding force of the grains and easily becomes the cracking initiation sites, especially in the coarser precipitates located at the triangle junction of three grains. Therefore, though attaining the better grain refinement for the $0.8 \mathrm{Ca}$ alloy, its strength and elongation all decrease.

Figure 7 clearly shows that the corrosion resistance decreases with the increase of $\mathrm{Ca}$ content. As is well known, the standard electrode potentials of the formed phases in $\mathrm{Mg}-\mathrm{Zn}$-Ca alloy are in the following order: $\mathrm{Ca}_{2} \mathrm{Mg}_{6} \mathrm{Zn}_{3}>\alpha-\mathrm{Mg}>\mathrm{Mg}_{2} \mathrm{Ca}^{[6,33]}$.

For the $0.8 \mathrm{Ca}$ alloy, $\mathrm{Mg}_{2} \mathrm{Ca}$ phase acts as an anode and $\mathrm{Mg}$ matrix as a cathode. With a large amount of corrosion of $\mathrm{Mg}_{2} \mathrm{Ca}$ phase, they are detached and corrosion holes would be formed. More seriously, with the corrosion continuing, these corrosion holes can even connect with each other and form corrosion cavities. In turn, the cavities can accelerate the corrosion process due to contacting more corrosive liquid. Thus it is easy to understand why the $0.8 \mathrm{Ca}$ alloy can obtain the worst corrosion resistance.

For the $0.2 \mathrm{Ca}$ alloy only two phases, i.e. $\alpha-\mathrm{Mg}+\mathrm{Ca}_{2} \mathrm{Mg}_{6} \mathrm{Zn}_{3}$, are formed. $\mathrm{Ca}_{2} \mathrm{Mg}_{6} \mathrm{Zn}_{3}$ phase can serve as a cathode while $\mathrm{Mg}$ matrix acts as an anode at the interface between $\mathrm{Ca}_{2} \mathrm{Mg}_{6} \mathrm{Zn}_{3}$ and $\mathrm{Mg}$ matrix. Due to the relatively lower amount of $\mathrm{Ca}_{2} \mathrm{Mg}_{6} \mathrm{Zn}_{3}$ (Fig. 2), the galvanic reaction between $\mathrm{Ca}_{2} \mathrm{Mg}_{6} \mathrm{Zn}_{3}$ and $\alpha-\mathrm{Mg}$ cannot be very serious compared with $0.8 \mathrm{Ca}$ alloy. Therefore, $0.2 \mathrm{Ca}$ alloy can obtain a higher corrosion resistance than $0.8 \mathrm{Ca}$ alloy. The difference of corrosion resistance between $0.2 \mathrm{Ca}$ and
$0.8 \mathrm{Ca}$ alloys can also be confirmed from their corroded surface morphologies as shown in Figs. 8 and 9.

For the $0 \mathrm{Ca}$ alloy, it can be seen that the amount of $\mathrm{Mg}_{2} \mathrm{Ca}$ phase precipitated is very much lower and thus the galvanic reaction is smaller. Therefore, the $0 \mathrm{Ca}$ alloy can obtain the highest corrosion resistance among all the alloys in this study.

\section{Conclusions}

In this study the effects of $\mathrm{Ca}$ content on the microstructure, mechanical behaviors and corrosion properties in the as-cast low-alloyed $\mathrm{Mg}-\mathrm{Zn}-\mathrm{Ca}$ alloys were investigated. Summarizing the results, the conclusions can be drawn as follows:

(1)With $\mathrm{Ca}$ addition, the grain is refined, and the amount of precipitated secondary phases increases with more $\mathrm{Ca}$ addition.

(2) Different precipitation behaviors of phases are observed for different Ca-containing alloys. As-cast microstructures of $0.2 \mathrm{Ca}$ alloy and $0.4 \mathrm{Ca}$ alloy are composed of $\alpha-\mathrm{Mg}$ and $\mathrm{Ca}_{2} \mathrm{Mg}_{6} \mathrm{Zn}_{3}$ phases while that of $0.8 \mathrm{Ca}$ alloys contain $\alpha-\mathrm{Mg}, \mathrm{Mg}_{2} \mathrm{Ca}$ and $\mathrm{Ca}_{2} \mathrm{Mg}_{6} \mathrm{Zn}_{3}$ phases as revealed by XRD and TEM analyses.

(3) With the increase of Ca content, ultimate tensile strength (UTS) and elongation to fracture all firstly increase and then decrease. Among three alloys, $0.2 \mathrm{Ca}$ alloy exhibits the best combination of UTS (161 MPa) and elongation to fracture $(9.1 \%)$, which can be explained from grain refinement and secondary phase strengthening.

(4) With the increase of $\mathrm{Ca}$ content, the corrosion rate increases correspondingly, which can be explained from characteristics of their different phases precipitated.

\section{References}

[1] Kubok K, Litynska-Dobrzynska L, Wojewoda-Budka J. Investigation of structures in as-cast alloys from the Mg- $\mathrm{Zn}-\mathrm{Ca}$ system. Archives of Metallurgy and Materials, 2013, 58: 329333.

[2] Zheng Yufeng. Magnesium alloys as degradable biomaterials: CRC Press, 2015. (In Chinese)

[3] Hofstetter J, Becker M, Martinelli E, et al. High-strength lowalloy (HSLA) Mg-Zn-Ca alloys with excellent biodegradation performance. JOM, 2014, 66: 566-572.

[4] Hofstetter J, Rüedi S, Baumgartner I, et al. Processing and microstructure-property relations of high-strength low-alloy (HSLA) Mg-Zn-Ca alloys. Acta Materialia, 2015, 98: 423-432.

[5] Bakhsheshi-Rad H, Hamzah E, Fereidouni-Lotfabadi A, et al. Microstructure and bio-corrosion behavior of Mg-Zn and Mg-Zn$\mathrm{Ca}$ alloys for biomedical applications. Materials and Corrosion, 2014, 65: 1178-1187.

[6] Geng L, Zhang B, Li A, Dong C. Microstructure and mechanical properties of Mg-4.0 Zn-0.5 Ca alloy. Materials Letters, 2009, 63: 557-559.

[7] Sun $Y$, Zhang B, Wang $Y$, et al. Preparation and characterization of a new biomedical Mg-Zn-Ca alloy. Materials \& Design, 2012, 34:58-64.

[8] Song J, Wang Z, Huang $Y$, et al. Effect of $Z n$ addition on hot tearing behaviour of Mg-0.5 Ca-xZn alloys. Materials \& Design, 2015, 87: 157-170.

[9] Tong L, Zheng M, Hu X, et al. Influence of ECAP routes on microstructure and mechanical properties of $\mathrm{Mg}-\mathrm{Zn}-\mathrm{Ca}$ alloy. 
Materials Science and Engineering: A, 2010, 527: 4250-4256.

[10] Tong L, Zheng M, Xu S, et al. Effect of Mn addition on microstructure, texture and mechanical properties of $\mathrm{Mg}-\mathrm{Zn}-\mathrm{Ca}$ alloy. Materials Science and Engineering: A, 2011, 528: 37413747.

[11] Tong L, Zheng M, Cheng L, et al. Effect of extrusion ratio on microstructure, texture and mechanical properties of indirectly extruded Mg-Zn-Ca alloy. Materials Science and Engineering: A, 2013, 569: 48-53.

[12] Hradilová M, Vojtěch D, Kubásek J, et al. Structural and mechanical characteristics of $\mathrm{Mg}-4 \mathrm{Zn}$ and $\mathrm{Mg} 4 \mathrm{Zn} 0.4 \mathrm{Ca}$ alloys after different thermal and mechanical processing routes. Materials Science and Engineering: A, 2013, 586: 284-291.

[13] Yu S, Kong M X, Jiao X H. In-vitro evaluation of Mg-4.0Zn-0.2Ca alloy for biomedical application. Transactions of Nonferrous Metals Society of China, 2011, 21:s252-s257.

[14] Chen S, Smith CE, Xu Z, et al. Development of biodegradable Mg-Zn-Ca alloys for biomedical applications. ASME 2010 International Mechanical Engineering Congress and Exposition: American Society of Mechanical Engineers, 2010: 43-48.

[15] Yin P, Li NF, Lei T, et al. Effects of Ca on microstructure, mechanical and corrosion properties and biocompatibility of Mg-Zn-Ca alloys. Journal of Materials Science: Materials in Medicine, 2013, 24: 1365-1373.

[16] Zander D, Zumdick NA. Influence of $\mathrm{Ca}$ and $\mathrm{Zn}$ on the microstructure and corrosion of biodegradable $\mathrm{Mg}-\mathrm{Ca}-\mathrm{Zn}$ alloys. Corrosion Science, 2015, 93: 222-233.

[17] Du H, Wei Z, Liu X, et al. Effects of Zn on the microstructure, mechanical property and bio-corrosion property of $\mathrm{Mg}-3 \mathrm{Ca}$ alloys for biomedical application. Materials Chemistry and Physics, 2011, 125: 568-575.

[18] Du Y, Zheng M, Xu C, et al. Microstructures and mechanical properties of as-cast and as-extruded Mg-4.50 Zn-1.13 Ca (w.\%) alloys. Materials Science and Engineering: A, 2013, 576: 6-13.

[19] Du Y, Zheng M, Qiao X, et al. The effect of double extrusion on the microstructure and mechanical properties of Mg-Zn-Ca alloy. Materials Science and Engineering: A, 2013, 583: 69-77.

[20] Bamberger M, Levi G, Vander Sande J. Precipitation hardening in Mg-Ca-Zn alloys. Metallurgical and Materials Transactions A, 2006, 37: 481-487.

[21] Zhang B, Wang Y, Geng L. Research on Mg-Zn-Ca alloy as degradable biomaterial. Biomaterials-Physics and Chemistry: InTech, 2011.
[22] Bakhsheshi-Rad H, Abdul-Kadir M, Idris M, et al. Relationship between the corrosion behavior and the thermal characteristics and microstructure of Mg-0.5Ca-xZn alloys. Corrosion Science, 2012, 64:184-197.

[23] Song Y, Han E-H, Shan D, et al. The role of second phases in the corrosion behavior of Mg-5Zn alloy. Corrosion Science, 2012, 60:238-245.

[24] Rad B, Reza H, Idris MH, et al. Characterization and corrosion behavior of biodegradable Mg-Ca and Mg-Ca-Zn implant alloys. Applied Mechanics and Materials: Trans Tech Publ, 2012: 568572.

[25] Li Z, Gu X, Lou S, et al. The development of binary Mg-Ca alloys for use as biodegradable materials within bone. Biomaterials, 2008, 29: 1329-1344.

[26] Zhang B, Geng L, Huang L, et al. Enhanced mechanical properties in fine-grained $\mathrm{Mg}-1.0 \mathrm{Zn}-0.5 \mathrm{Ca}$ alloys prepared by extrusion at different temperatures. Scripta Materialia, 2010, 63: 1024-1027.

[27] Li H X, Qin S K, Ma Y Z, et al. Effects of Zn content on microstructure, mechanical and corrosion properties of as-cast low-alloyed Mg-Zn-Ca alloys. International Journal of Minerals, Metallurgy and Materials, 2017, submitted.

[28] Nayeb-Hashemi A. Phase diagrams of binary magnesium alloys. ASM International, Metals Park, Ohio 44073, USA, 1988: 370.

[29] Liu C M, Zhu X R, Zhou H T. Phase Diagrams of Magnesium Alloys. Central South University Press, Changsha, 2006: 186187. (In Chinese)

[30] Li S S, Tang B, Zeng D B. Effects and mechanism of Ca on refinement of AZ91D alloy. Journal of Alloys and Compounds, 2007, 437: 317-321.

[31] Takeuchi A, Inoue A. Classification of Bulk Metallic Glasses by Atomic Size Difference, Heat of Mixing and Period of Constituent Elements and Its Application to Characterization of the Main Alloying Element. Materials Transactions, JIM, 2005, 46: 28172829.

[32] Petch N J. The Cleavage Strength of Polycrystals. Journal of the iron and steel institute, 1953, 174: 25-26.

[33] Zhang Erlin, Lei Yang. Microstructure, mechanical properties and bio-corrosion properties of Mg-Zn-Mn-Ca alloy for biomedical application. Materials Science and Engineering: A , 2008, 497(1): 111-118.

This research was supported by National Natural Science Foundation of China (51671017), Fundamental Research Funds for the Central Universities (No. FRF-GF-17-B3), Beijing Laboratory of Metallic Materials and Processing for Modern Transportation, the Opening Research Fund of State Key Laboratory for Advanced Metals and Materials (No. 2016Z-11, 2017Z-08), the fund of the State Key Laboratory of Solidification Processing in NWPU (SKLSP201835) and State's Key Project of Research and Development Plan (No.2016YFB0300801) 